\title{
Columnar Cell Hyperplasia of the Breast
}

National Cancer Institute

\section{Source}

National Cancer Institute. Columnar Cell Hyperplasia of the Breast. NCI Thesaurus. Code C54183.

A columnar cell lesion characterized by the presence of enlarged terminal ductal lobular units with dilated acini. The acini are lined by more than two layers of columnar epithelial cells. Prominent apical cytoplasmic snouts are present. Secretions are often present in the lumina of the dilated acini. 